\title{
Struktur Bumi di bawah Australis melalui Analisis dan Pencocokan Seismogram Gempa Intra Plate C081097A pada Stasiun Observasi TAU, CTAO and NWAO
}

\author{
Bagus Jaya Santosa* \\ Jurusan Fsika-FMIPA, Institut Teknologi Sepuluh Nopember \\ Kampus ITS Sukolilo, Surabaya 61111
}

\begin{abstract}
Intisari
Dalam penelitian ini struktur bumi di bawah Australia diinvestigasi melalui analisis seismogram observasi akibat gempa C081097A, Western Australia, dan seismogram sintetik milik stasiun observasi TAU, CTAO dan NWAO, dalam domain waktu dan ketiga komponen Kartesian secara simultan. Seismogram sintetik dihitung dengan program GEMINI, dimana input awalnya adalah model bumi IASPEI91 dan PREMAN. Selain itu pada kedua seismogram dikenakan low-pass filter dengan frekuensi corner pada $20 \mathrm{mHz}$. Hasil analisis menunjukkan penyimpangan yang sangat kuat tentang tidak sistimastisnya waktu tiba, jumlah osilasi dan tinggi amplitudo, pada gelombang P, S dan gelombang permukaan Rayleigh dan Love. Dengan metoda ini terlihat bagaimana pekanya waveform terhadap struktur perlapisan bumi.Untuk menyelesaikan diskrepansi yang dijumpai diperlukan koreksi atas struktur bumi meliputi ketebalan kulit bumi, gradient kecepatan $\beta_{h}$ dan besar koefisien-koefisien untuk $\beta_{h}$ dan $\beta_{v}$ di Upper Mantle, dan sedikit perubahan pada kecepatan $\mathrm{P}$ dan S struktur pada lapisan-lapisan bumi hingga CMB. Pencocokan (fitting) seismogram diperoleh dengan baik pada waveform fase gelombang, baik waktu tempuh osilasi utama dan jumlah osilasi. Walaupun panjang gelombang adalah sekitar $150 \mathrm{~km}$, tomografi waveform pada gelombang body dan gelombang permukaan dalam domain waktu menunjukkan kepekaan terhadap perubahan ketebalan kulit bumi dan struktur kecepatan.
\end{abstract}

KATA KUNCI: pencocokan seismogram, model kecepatan Upper Mantle - CMB

\section{PENDAHULUAN}

Gempa C081097A merupakan gempa kuat yang terjadi pada tanggal 10 Agustus 1997 di Western Australia dengan skala Richter 5,9. Akibat gempa ini seluruh isi bumi terguncang, sehingga semua tempat di permukaan bumi dapat merasakan getaran tanah akibat gempa tsb.

Getaran/Pergerakan tanah dapat diukur, melalui seismometer di stasiun penerima, diubah dari kecepatan atau percepatan $\left[\mathrm{mm} / \mathrm{s}\right.$ atau $\left.\mathrm{mm} / \mathrm{s}^{2}\right]$ menjadi tegangan listrik $(\mathrm{mV})$, direkam sebagai deret waktu dan disajikan kembali sebagai seismogram. Seismogram adalah data runtun waktu yang tersusun atas fase-fase gelombang yang kompleks, berasal dari refleksi/refraksi yang terjadi di dalam bumi. Ini menunjukkan adanya perbedaan parameter elastik pada sistem perlapisan model bumi. Gelombang dalam perambatannya dari sumber gempa hingga stasiun penerima menjumpai berbagai antarmuka, sehingga seismogram tersusun atas berbagai fase gelombang yang rumit.

Studi tentang struktur internal bumi, khususnya struktur halus di daerah zona transisi upper mantle dan D”, adalah salah satu piranti utama untuk mendapatkan batasan-batasan pada proses-proses geodinamik. Satu pendekatan (misal [1]) mengarah pada inversi langsung untuk struktur bumi global. Namun lingkupan yang bersifat global adalah jarang. Dalam

*E-MAIL: bjs@physics.its.ac.id beberapa hal adalah bermanfaat untuk mengumpulkan profil 1-D diperluas dari sebuah region geografik yang kecil dan menginversikan struktur 1-D untuk daerah geografis yang dikaji tersebut.

Dalam beberapa studi kasus struktur bumi 1-D, informasi penting yang terkandung dalam fase-fase seismik yang saling overlapping, seperti triplikasi di upper mantle atau S dan ScS untuk region D"; perbandingan seismogram sintetik ke data terukur sebagai langkah vital dalam menganalisis data. [2].

Analisis kuantitatif utama dalam analisis seismogram adalah dengan mencatat waktu-waktu tiba fase gelombang utama dan hubungan antara kecepatan fase/grup dengan perioda-perioda pada gelombang permukaan, yang disebut sebagai analisis dispersi. Data waktu tiba yang paling mudah diukur adalah first break $\mathrm{P}$.

Himpunan data waktu tempuh yang dibentuk oleh pasangan hiposenter - stasiun-stasiun observasi atas berbagai fase gelombang dari ribuan gempa bumi, dalam waktu puluhan tahun dapat mencapai jumlah hingga jutaan data. Struktur model bumi, IASPEI91 [3], SPREM [4] dan model-model bumi lanjutan dengan resolusi yang lebih rinci dari kedua model bumi standar diturunkan dari data waktu tempuh. Parameter elastik yang diperoleh dengan metoda waktu tempuh gelombang hanya kecepatan rambat gelombang $\mathrm{P}$ dan $\mathrm{S}$. Parameter elastik yang lain, misal rapat massa, faktor kualitas redaman dan anisotropi didapatkan dengan menggunakan metoda analisis dispersi pada gelombang permukaan per komponen Kartesian, dimana dicari hubungan antara kecepatan fase/grup gelombang terhadap perioda. 


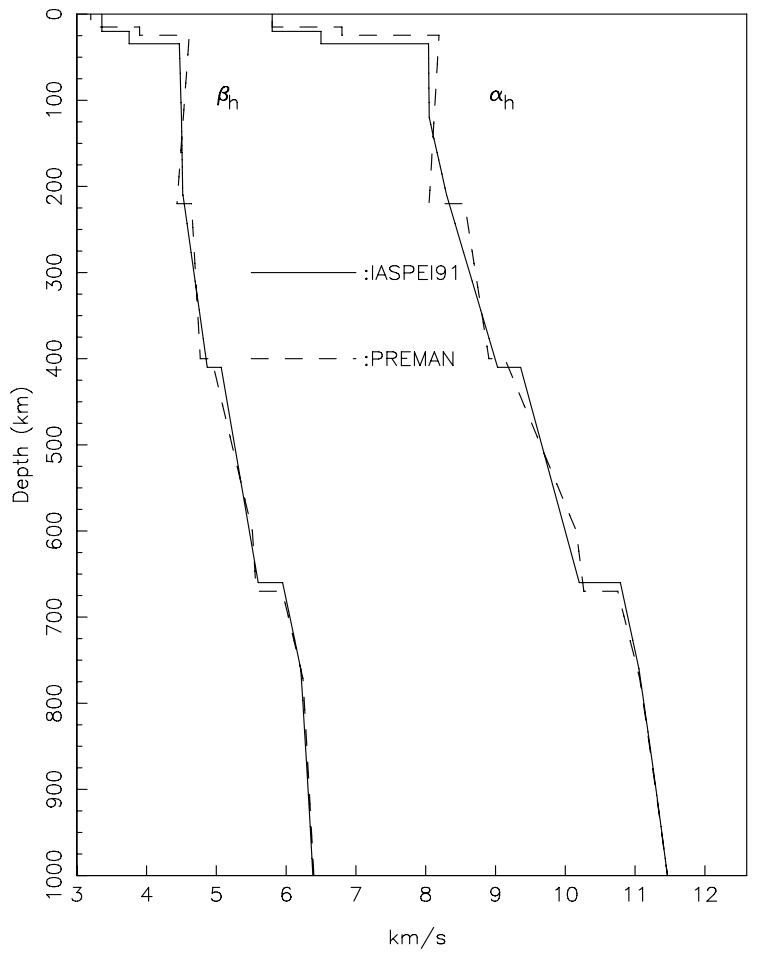

Gambar 1: Penampang model bumi dari model bumi standard isotrop IASPEI91 dan vertikal anisotrop PREMAN hingga kedalaman 1000 $\mathrm{km}$

Model bumi yang terkenal, yang sering diajukan sebagai model referensi oleh para ahli seismology, yaitu IASPEI91 dan PREMAN (versi anisotropi dari SPREM) dapat dilihat pada Gambar 1 hingga kedalaman $1000 \mathrm{~km}$.

Dua metoda kuantitatif yang digunakan untuk menganalisis seismogram di atas hanya mengevaluasi sedikit informasi tertentu dalam sebuah deret waktu seismogram. Penelitian dalam tulisan ini menggunakan metoda analisis waveform seismogram riil dan sintetiknya dalam domain waktu, ketiga komponen Kartesian secara simultan. Apakah model-model bumi standard yang didapat dengan mengolah sedikit informasi dalam seismogram dapat memberikan kembali seismogram sintetik yang menyerupai seismogram observasi dalam ketiga komponen?, walaupun analisis seismogram dilaksanakan dengan frekuensi corner pada $20 \mathrm{mHz}$.

Metoda yang digunakan dalam riset ini memanfaatkan keseluruhan informasi dalam seismogram domain waktu dan ketiga komponen Kartesian secara simultan. Akan kita lihat, bagaimana pekanya waveform terhadap struktur perlapisan bumi. Ini berbeda dengan tomografi pada daerah yang sama (Australia), yang didasarkan pada analisis waktu tiba gelombang P \& S [5] dan analisis dispersi, yang hanya dilakukan pada gelombang Rayleigh komponen vertikal $[6,7]$ dan Love wave secara terpisah [8], dimana hanya sedikit informasi dalam seismogram dimanfaatkan.

Metoda analisis seismogram dalam domain waktu dan ketiga komponen secara simultan adalah yang terbaik [9, 10]. Seimogram sintetik dihitung dengan program GEM-
TABEL I: Daftar gempa bumi yang terjadi di Intra Plate Australia

\begin{tabular}{ccccc}
\hline \hline Kode & Lintang & Bujur & $\begin{array}{c}\text { Kedalaman } \\
\text { \& Magnitude }\end{array}$ & Lokasi \\
\hline & & \multicolumn{3}{c}{} \\
B042379B & $-16,54$ & 120,18 & $33,05 / 95,7$ & NW AUSTRALIA \\
C060279A & $-30,81$ & 117,18 & $6,06 / 06,1$ & W AUSTRALIA \\
B033086A & $-26,23$ & 132,70 & $10,05 / 75,8$ & S AUSTRALIA \\
B071186A & $-26,22$ & 132,84 & $10,05 / 65,4$ & S AUSTRALIA \\
C012288A & $-19,90$ & 133,81 & $5,06 / 16,3$ & N AUSTRALIA \\
C012288B & $-19,81$ & 133,91 & $5,06 / 16,4$ & N AUSTRALIA \\
C012288C & $-19,88$ & 133,88 & $5,06 / 56,7$ & N AUSTRALIA \\
C081097A & $-16,01$ & 124,33 & $10,05 / 96,0$ & W AUSTRALIA \\
\hline \hline
\end{tabular}

INI $[11,12]$, dimana inputnya adalah model bumi elastik secara lengkap, keterangan CMT dari gempa B081097A dan kedudukan stasiun-stasiun observasi TAU, CTAO \& NWAO. Guna membandingkan seismogram riil dan sintetik dalam dimensi yang sama, digunakan file response dari stasiunstasiun observasi tersebut. Data seismogram adalah milik The Incorporated Research Institutions for Seismology (IRIS, http://www.iris.edu), dan diambil per download via HTTP.

\section{METODOLOGI PENELITIAN}

Ada beberapa gempa bumi yang terjadi di dalam pelat benua Australia dimana besar gempa dipersyaratkan mempunyai skala Richter di atas 5,4. Ini diperlukan agar waveform pada ketiga komponen dapat dianalisis dengan jelas, seperti tercantum dalam Tabel I.

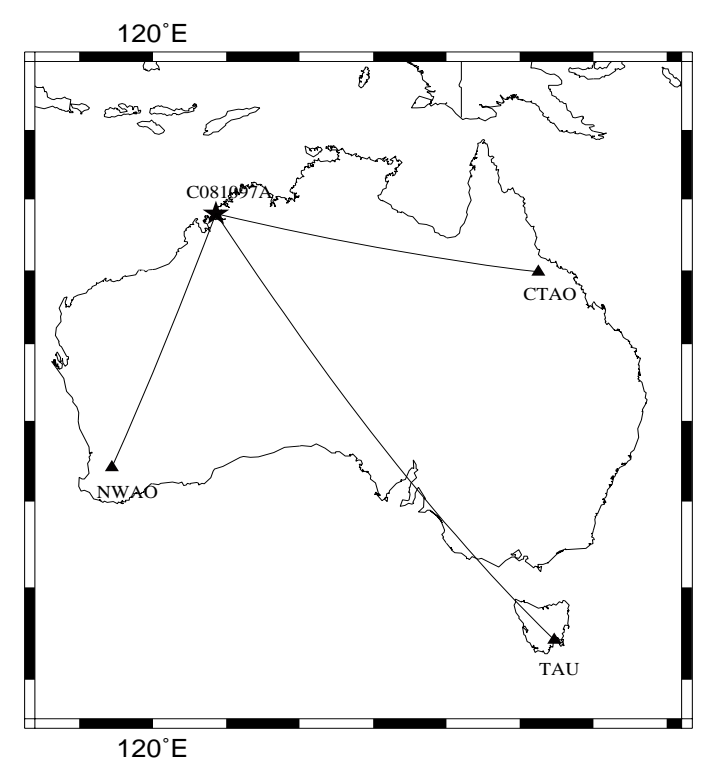

Gambar 2: Jalan Gelombang dari Episenter hingga Stasiun-stasiun Observasi TAU, NWAO \& CTAO

Namun dari sekian gempa terinci ini, hanya gempa terakhir yang dapat diakses secara digital dari Datacenter. Gempa- 
gempa yang terjadi sebelum 1992 direkam secara analog, sehingga versi digitalnya tidak tersedia (Jawab dari data center: "No data"). Oleh karena itu riset ditujukan untuk membuat analisis atas gempa terakhir saja. Gambar 2 menyajikan jalanjalan gelombang dari epicenter gempa terakhir ke stasiunstasiun observasi yang digunakan dalam riset ini.

Data seismogram dapat diperoleh dari Databank Center, yang datanya dapat diakses per WWW. Setiap gempa menghasilkan pergerakan tanah, yang oleh sebuah stasiun akan direkam dalam arah ketiga komponen Kartesian (N-S, E-W and vertikal Z, lokal pada kedudukan stasiun penerima, dikenal sebagai kanal dengan akhiran -E -N \&- Z). Kedudukan sumber gempa adalah di Western Australia, dengan koordinat $16.01^{0}$ Lintang Selatan dan $124.33^{0}$ Bujur Timur. Untuk memisahkan komponen pergerakan tanah dalam arah toroidal dan radial, bidang horisontal yang dibentuk oleh garis $\mathrm{N}-\mathrm{S}$ dan E-W lokal di stasiun observasi harus diputar, sedemikian hingga arah 'Utara' lokal diarahkan pada arah busur kecil dari stasiun observasi ke arah episenter gempa, lihat Gambar 2. Pengubahan arah diperlukan untuk memisahkan komponenkomponen penjalaran gelombang menjadi mode gelombang P-SV dan SH.

Pertama dalam penelitian ini harus dijalankan program komputer untuk melaksanakan perhitungan atas waktu tempuh sintetik fase-fase gelombang ruang utama, yaitu program TTIMES yang dibuat berdasarkan makalah Bulland \& Chapman [13](http://orfeus.knmi.nl.). Sedangkan untuk memproduksi seismogram sintetik dari gempa tersebut di stasiun observasi digunakan program yang berbasis metoda GEMINI (Green's function of the Earth by MINor Integration).

Program GEMINI adalah menghitung minor dari fungsifungsi Green's atas suatu model bumi dan untuk suatu kedalaman sumber gempa tertentu. di mana fungsi-fungsi Green's diekspansikan untuk memenuhi kondisi syarat batas di titik terdalam gelombang, titik kedalaman sumber dan permukaan bumi. Ekspansi dituliskan dalam frekuensi komplex, dengan memasukkan trick damping untuk menghindari time aliasing. Program DISPEC (termasuk paket GEMINI) membaca posisi stasiun-stasiun penerima dan parameter-parameter moment tensor, yang tertera dalam solusi CMT baris ketiga. Posisi geographi episenter dan stasiun penerima ditranformasikan ke dalam koordinat pusat episenter (jarak episentral dan azimut) dan dihitung harmonik spherical untuk semua stasiun penerima. Program DISPEC membaca solusi basis Green's dari GEMINI, dan membentuk sumasi atas harmonik spferis dan mengadakan transformasi balik ke koordinat geografis. Hasilnya adalah seismogram sintetik dalam kawasan frekuensi komplex. Program MONPR, mentranform seismogram sintetik frekuensi komplex ke time domain, dimana sebelumnya dikenakan filter lolos rendah Butterworth dan RESPONSE file dari sistem peralatan seismometer di stasiun penerima, sehingga seismogram sintetik dan seismogram riil dibandingkan dalam dimensi yang sama.

Ketika program ini dijalankan, haruslah sebuah model bumi diberikan sebagai input awal, yaitu model bumi IASPEI91 dan PREMAN. Sebagai model bumi masukan, data harus mengandung parameter elastik secara lengkap, yaitu meliputi kecepatan penjalaran gelombang kompresi dan shear dari batuan

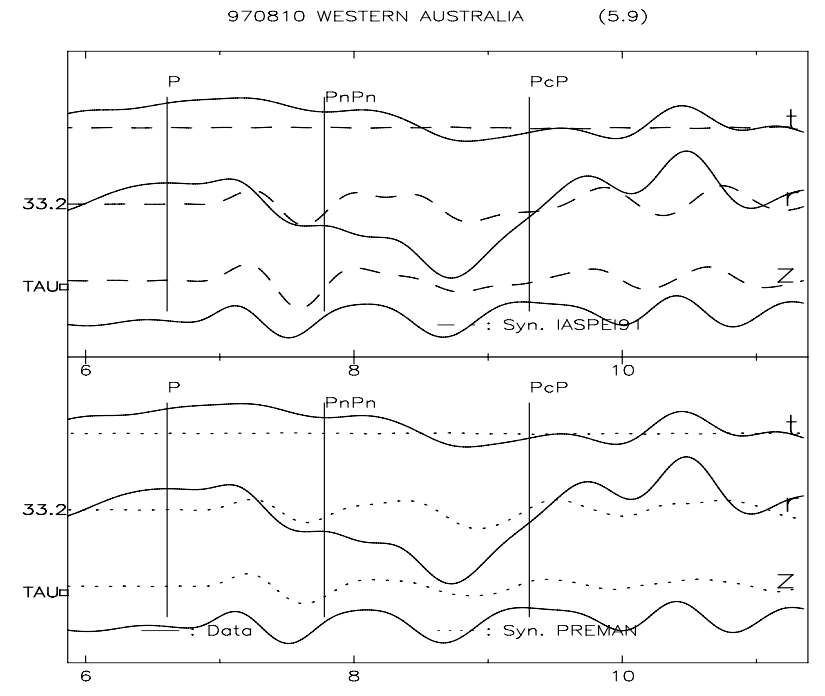

(a)P Wave

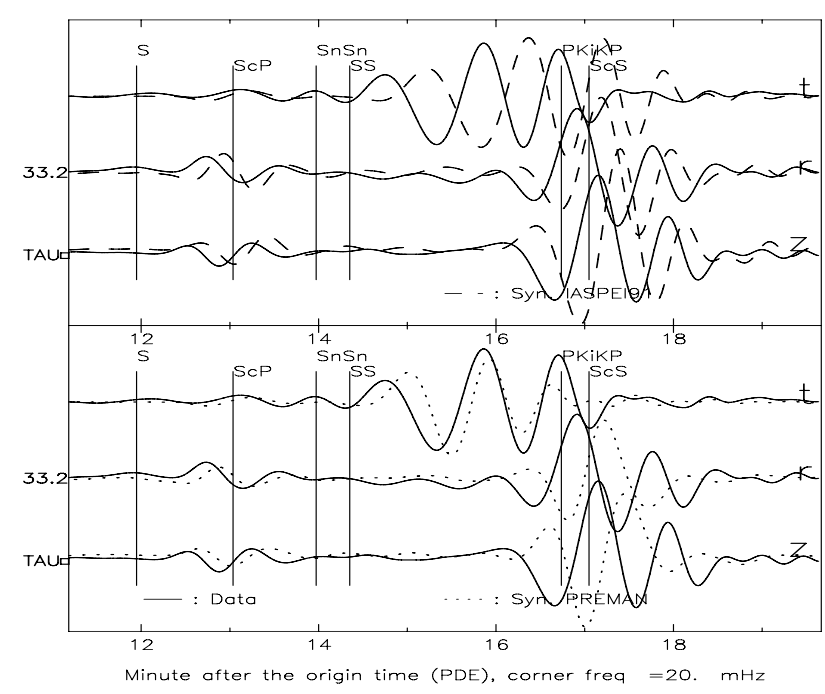

(b)S, R \& L Wave

Gambar 3: Perbandingan seismogram dan travel time dalam kawasan waktu dengan corner frequency $20 \mathrm{mHz}$ di stasiun observasi TAU, dalam segmen waktu gelombang a). $\mathrm{P}, \mathrm{b}$ ). $\mathrm{S}$ dan permukaan

penyusun struktur bumi. Parameter elastik dalam model bumi IASPEI91 tidaklah selengkap parameter elastik dalam model bumi PREMAN, sehingga parameter elastik yang tidak dimiliki, dipinjamkan dari model bumi PREMAN.

Jumlah data dalam komparasi seismogram pada tiga komponen adalah ribuan, sehingga perubahan ketebalan kulit bumi, gradient kecepatan, dan besar koefisien awal fungsi polinomial kecepatan di tiap lapisan bumi dilakukan melalui metoda trial and error.

\section{ANALISIS DAN PEMBAHASAN}

Dalam penelitian ditampilkan analisis sebuah gempa West Australia, 10 Agustus 1997, yang gelombangnya ditangkap 


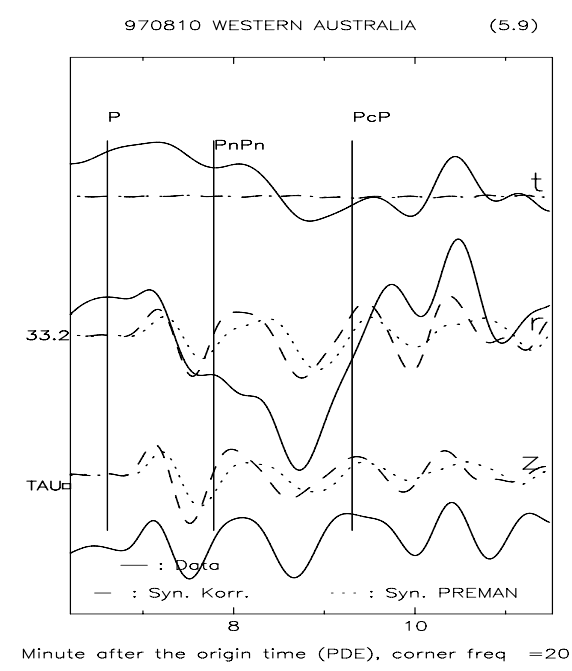

(a)P Wave

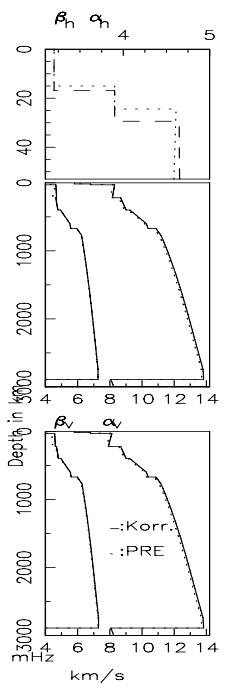

$\mathrm{km} / \mathrm{s}$

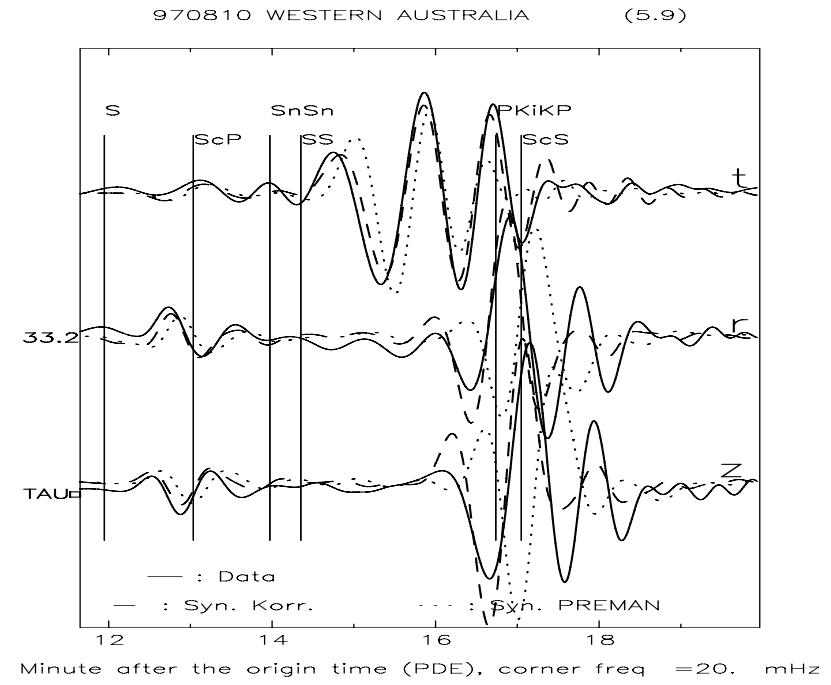

(b)S, R \& L Wave

Gambar 4: Pencocokan seismogram C081097A di stasiun observasi TAU dalam segmen waktu a. gelombang P dan b. gelombang S dan permukaan

oleh stasiun-stasiun observasi seismologi TAU, CTAO, dan NWAO Australia

Gambar 3 dan selanjutnya memperlihatkan seismogram dalam tiga komponen dan perbandingan seismogram observasi dengan sintetiknya yang dihitung dari model bumi IASPEI91 dan PREMAN. Satu set gambar bawah menunjukkan perbandingan dengan seismogram sintetik dihitung dari model bumi PREMAN, dan set atas dari IASPEI91. Identifikasi gelombang menggunakan waktu-waktu tempuh gelombang utama yang dihitung dengan TTIMES dari model bumi IASPEI91 (dinyatakan sebagai garis vertikal dalam gambar). Satu set gambar terdiri atas 3 trace, trace paling bawah adalah komponen gerakan vertikal z, kedua adalah komponen radial dan paling atas adalah komponen toroidal. Sumbu datar menyatakan sumbu waktu dalam menit setelah terjadinya gempa bumi (Origin Time, menurut keterangan PDE), sedangkan sumbu tegak menyatakan perbandingan amplitudo.

Pertama akan ditunjukkan, bagaimana analisis seismogram dilaksanakan pada frekuensi corner yang dipasang pada 20 $\mathrm{mHz}$. Perbandingan seismogram riil dan sintetik-sintetiknya dalam segmen waktu gelombang kompresi P diilustrasikan dalam Gambar 3(a). Terlihat kedua waveorm P sintetik, baik dari PREMAN ataupun IASPEI91 mempunyai waktu tiba gelombang $\mathrm{P}$ yang terlambat 6 sekon dibanding riilnya. Pada waveform $\mathrm{PnPn}$, kedua sintetik memberikan usikan dengan amplitudo yang lemah. Gambar 3(b) memberikan ilustrasi perbandingan seismogram dalam segmen waktu gelombang $\mathrm{S}$ hingga gelombang Love dan Rayleigh. Terlihat gelombang $S$ sintetik datang 6 sekon lebih lambat daripada $S$ riil sedangkan diskrepansi pada gelombang permukaan tampak sangat ramai. Gelombang Rayleigh sintetik terlambat 12 sekon dan Love sintetik 28 sekon. Gelombang Love riil memiliki tiga maksimum, sementara gelombang Love sintetik dari IASPEI91 juga memiliki tiga maksimum dengan keterlambatan yang cukup besar terhadap gelombang Love riil, sedangkan Love sintetik dari PREMAN hanya memiliki dua maksimum dan keterlambatan yang lebih kecil daripada Love IASPEI91.

Masalah yang diselesaikan dalam riset ini adalah pencocokan pada gelombang permukaan, meliputi waktu tiba dan jumlah osilasi pada gelombang Love dan waktu tiba gelombang Rayleigh. Gelombang permukaan merambat sepanjang permukaan dari sumber gempa hingga stasiun pengamatan, hingga suatu kedalaman yang ekivalen dengan panjang gelombang permukaan [14]. Oleh karena itu struktur kecepatan di upper mantle akan diubah sedemikian hingga dicapai pencocokan antara seismogram observasi dan sintetiknya, pertama pada gelombang permukaan.

Model bumi IASPEI91 dibentuk hanya dari data waktu tempuh, sehingga parameter elastis yang dihasilkan semata kecepatan penjalaran gelombang kompresi dan shear. Adalah mengherankan, bahwa model bumi IASPEI91 dapat memberikan pencocokan yang lebih baik dari model PREMAN pada gelombang Love, apakah ini hanya disebabkan oleh perbedaan ketebalan kulit bumi. Disamping itu model bumi IASPEI91 berupa model dengan kecepatan rambat gelombang yang isotrop, padahal dari perbandingan seismogram pada segmen gelombang permukaan cukup jelas terlihat, bahwa model bumi hendaknya anisotrop untuk dapat melaksanakan inversi pada kedua ragam gelombang permukaan secara bersamaan. Oleh karena itu untuk selanjutnya perbandingan seismogram didasarkan pada seismogram sintetik yang dihasilkan dari model bumi PREMAN dan model bumi dikoreksi.

Koreksi dilakukan pada lapisan upper mantel, dimana perubahan meliputi kedalaman Moho, penggunaan gradien positif untuk $\beta_{h}$ dan koefisien order nol pada polinomial untuk kecepatan $\beta_{h}$ dan $\beta_{v}$. Sementara gradient untuk $\beta_{v}$ dibiarkan seperti semula. Hasil dari koreksi ini dapat dilihat pada gambar 4(a) untuk segmen gelombang $\mathrm{P}$, dimana 


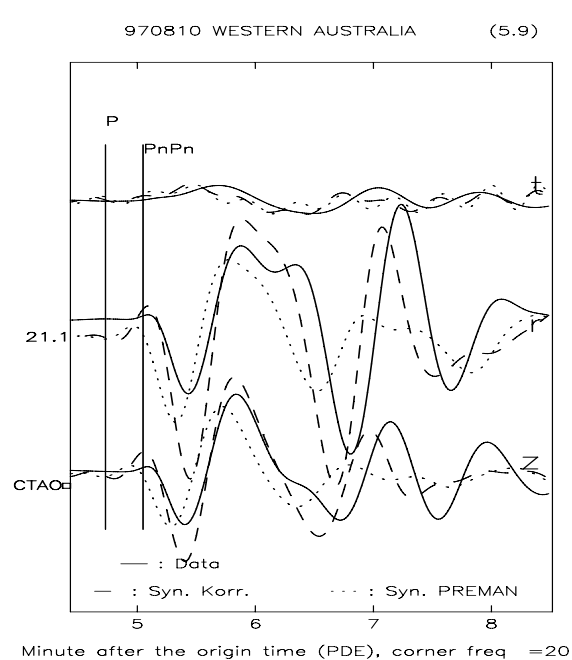

(a)P Wave

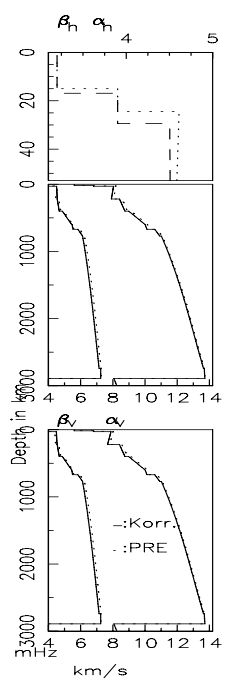

$\mathrm{km} / \mathrm{s}$

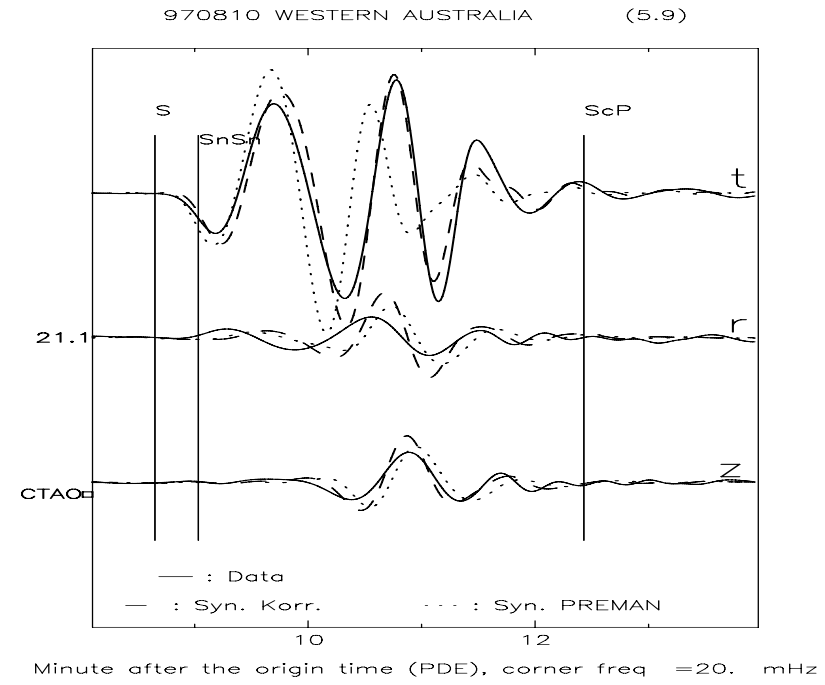

(b)R \& L Wave

Gambar 5: Pencocokan seismogram C081097A di stasiun observasi CTAO dalam segmen waktu a. gelombang P dan b. gelombang permukaan

$P$ sintetik dikoreksi memiliki waktu tiba yang sama dengan $\mathrm{P}$ riil, dan juga fase PnPn disimulasikan dengan lebih baik, walaupun fase PcP sintetik datang 6 sekon lebih awal daripada PcP riil. Ini masih menjadi masalah untuk riset berikutnya untuk mengkoreksi kecepatan $\mathrm{P}$ hingga kedalaman CMB, sedemikian hingga pencocokan pada PcP dapat dicapai. Gambar 4(b) menunjukkan perbandingan seismogram pada segmen waktu gelombang S hingga gelombang Love dan Rayleigh, terlihat S sintetik mengsimulasi waktu tiba gelombang S riil dengan baik. Tampak mengherankan, bahwa pencocokan pada gelombang Love juga dapat dicapai dengan sangat baik, baik pada waktu tiba ataupun jumlah osilasi. Ini dicapai dengan perubahan kulit bumi menjadi $30 \mathrm{~km}$. Awal dari gelombang Love disimulasikan dengan sangat baik. Terlihat jumlah osilasi dalam gelombang Love berreaksi peka terhadap perubahan kedalaman Moho, namun jumlah osilasi dalam gelombang Rayleigh tidak berreaksi sama sekali. pencocokan untuk gelombang Rayleigh pada komponen $\mathrm{z}$ dan $\mathrm{r}$ dilakukan hanya dengan mengubah koefisien order nol pada polinomial $\beta_{v}$ di upper mantle.

Berikutnya adalah analisis dan pencocokan seismogram di stasiun observasi CTAO. Perhatikan perbandingan seismogram pada segmen waktu gelombang P untuk stasiun observasi CTAO, seperti diilustrasikan dalam Gambar 5(a). Sintetik $\mathrm{P}$ dari PREMAN datang 7 sekon lebih awal daripada $\mathrm{P}$ riil, jika komparasi dilakukan per waveform, diperlukan perubahan kecepatan hingga CMB agar dicapai pencocokan yang baik, pada waktu tiba ataupun tinggi amplitudo gelombang $\mathrm{P}$, seperti terlihat pada komponen $\mathrm{z}$. Kita dapat mengamati keberadaan fase gelombang dengan amplitudo yang cukup besar berada di menit ke 7 . Fase ini disimulasikan dengan baik oleh seismogram dikoreksi, walaupun gelombang sintetik datang 10 sekon lebih awal daripada riil. Fase ini tidak dinotasikan oleh program TTIMES. Gambar 5(b) menunjukkan komparasi dan pencocokan untuk gelombang Love. dengan memasang kedalaman Moho pada $30 \mathrm{~km}, 5 \mathrm{~km}$ lebih

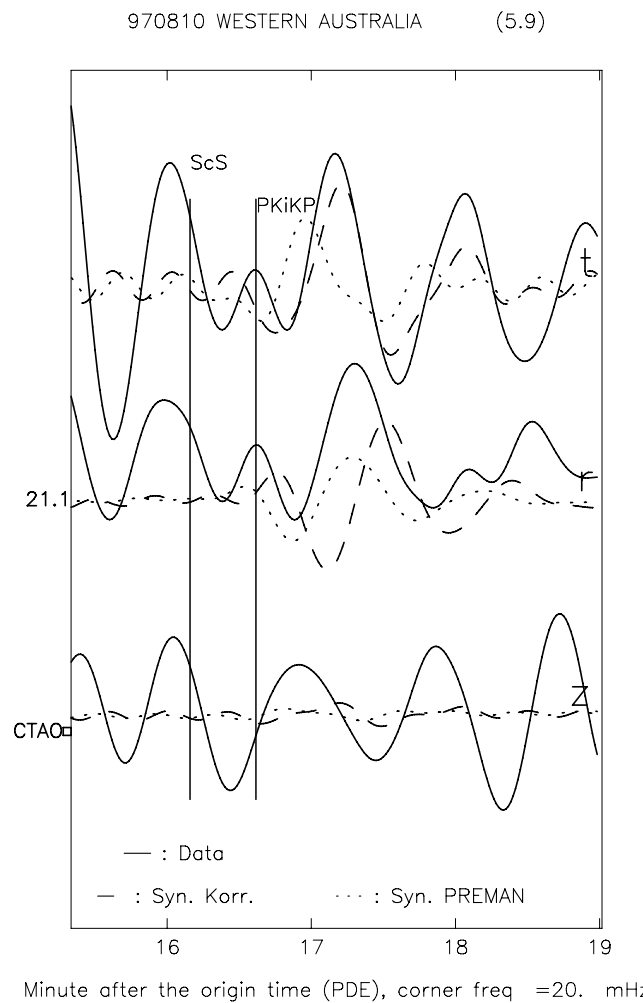

Gambar 6: Pencocokan seismogram C081097A di stasiun observasi CTAO dalam segmen waktu gelombang $\mathrm{ScS}$

tebal dari kedalaman Moho pada model bumi PREMAN, jumlah osilasi dalam gelombang Love riil dapat disimulasikan dengan baik oleh seismogram dikoreksi. pencocokan meliputi waktu tiba, tinggi amplitudo dan jumlah osilasi dalam gelombang Love. Sementara itu gelombang Rayleigh berreaksi 


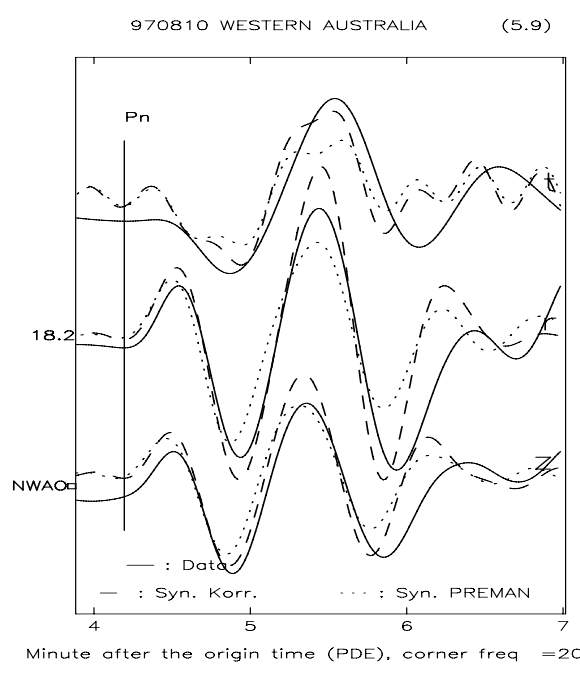

(a)P Wave

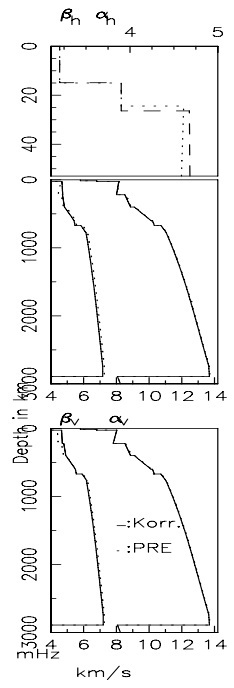

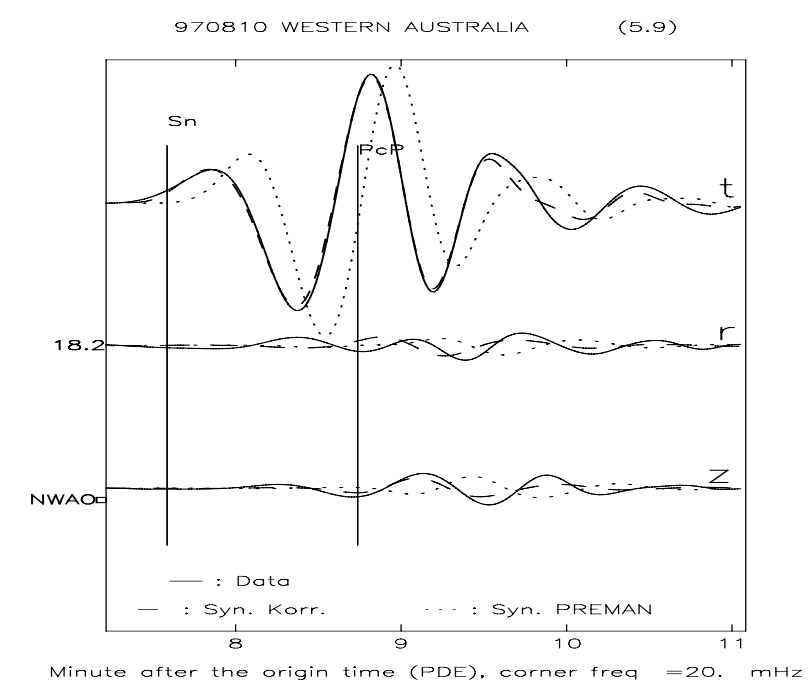

(b)R \& L Wave

Gambar 7: Pencocokan seismogram C081097A di stasiun observasi NWAO dalam segmen waktu a. gelombang P dan b. gelombang permukaan

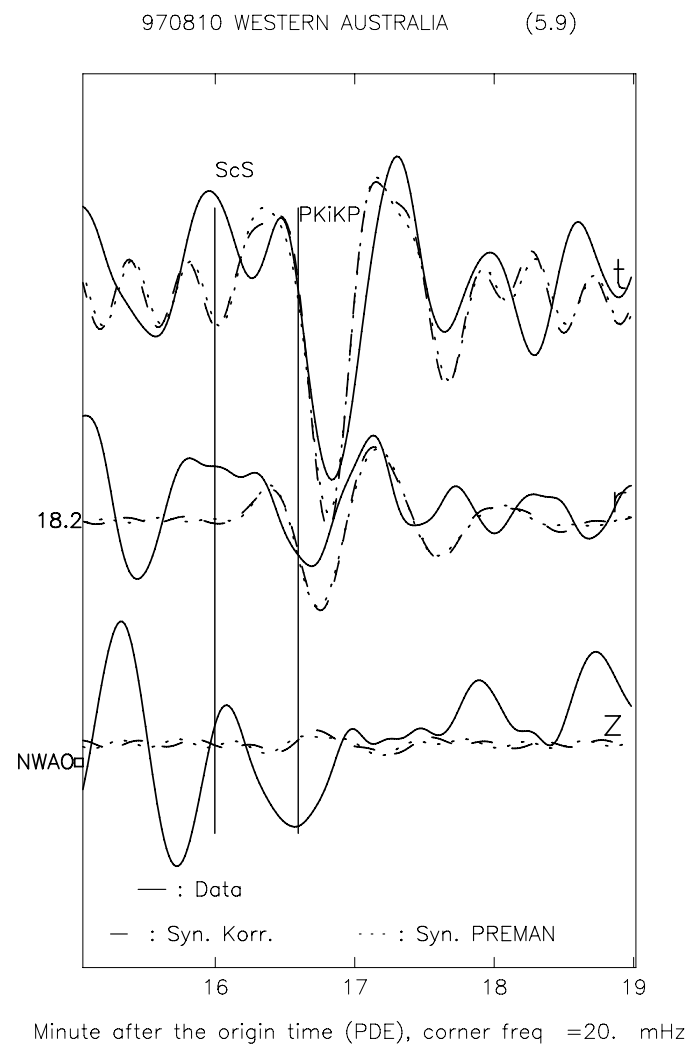

Gambar 8: Pencocokan seismogram C081097A di stasiun observasi NWAO dalam segmen waktu gelombang $\mathrm{ScS}$

sedikit terhadap perubahan kedalaman Moho ini. Gambar 6 menunjukkan perbandingan seismogram dan efek perubahan kecepatan di lapisan atas model bumi terhadap gelombang $\mathrm{ScS}$ di komponen $\mathrm{t}$ (menit 16,7). Kita amati fase gelombang
ScS dari PREMAN datang lebih awal 10 sekon dan dengan amplitudo yang lebih lemah dari $\mathrm{ScS}$ riil, sedangkan seismogram dikoreksi memberikan pencocokan yang baik, pada waktu tempuh dan tinggi amplitudo gelombang ScS.

Berikutnya kita analisis seismogram yang direkam oleh stasiun observasi NWAO. Gambar 7(a) menunjukkan perbandingan seismogram riil dan sintetik-sintetiknya, dari model PREMAN dan dikoreksi, pada segmen waktu gelombang $\mathrm{P}$ di stasiun observasi NWAO. Terlihat pada komponen $r$ dan $\mathrm{z}$ (gelombang PV), minimum pertama dari P sintetik PREMAN datang 5 sekon lebih awal daripada minimum pertama Pn riil, sedangkan sintetik Pn dikoreksi memberikan pencocokan dengan baik. Jarak dari episenter ke stasiun obsevasi NWAO adalah $18.2^{0}$, jarak antara gelombang $\mathrm{S}$ dan Love sangat dekat, sehingga gelombang $\mathrm{S}$ tenggelam dalam gelombang Love, diilustrasikan dalam gambar 7(b). Gelombang Love dikoreksi mendekati gelombang Love riil dengan sangat baik, pada waktu tiba, tinggi amplitudo, jumlah osilasi dan panjang osilasi. Pengamatan lanjut dilaksanakan pada gelombang ScS. Kita melihat di gambar 8, bahwa gelombang ScS terlihat di komponen $r$ dan $t$. Saya telah mengupayakan pencocokan pada kedua fase $\mathrm{ScS}$, ternyata struktur kecepatan $\beta_{v}$ di mantel bawah memberikan kontribusi yang signifikant pada waktu tempuh fase $\mathrm{ScS}$ di komponen t. Jika pencocokan pada ScS di komponen $t$ dicapai, ScS sintetik pada komponen $r$ akan datang terlambat (dibanding $\mathrm{ScS}$ riil). Ini berarti bahwa penyimpangan dari isotropi teramati juga di daerah mantel bawah.

Dari serangkaian pengamatan dan pencocokan seismogram pada gambar-gambar di atas dapat disimpulkan, bahwa waveform gelombang Love sangat peka dipengaruhi oleh ketebalan kulit bumi. Efek ini juga dapat dilihat pada amplitudo gelombang ruang. Efek dari ketebalan kulit bumi terhadap tinggi amplitudo belum dimanfaatkan untuk penentuan moment tensor, sebagaimana tercantum dalam penentuan Solusi tensor CMT [17]. Variasi kedalaman Moho sebagai hasil dari tomografi dengan gelombang Love belum diaplikasikan pada 
metoda-metoda tomografi struktur bumi berbasis kurva dispersi.

\section{SIMPULAN}

Dalam riset ini telah diteliti struktur bumi di bawah Australia melalui perbandingan seismogram gempa C081097A, Western Australia dengan stasiun observasi di CTAO, NWAO dan TAU. Seismogram sintetik dihitung dengan metoda GEMINI, yang ekivalen dengan metoda Mode Sumasi, namun perhitungan dilakukan dalam kawasan frekuensi komplex, menghasilkan seismogram lengkap dalam domain waktu dan ketiga komponen Kartesian. Perbandingan seismogram riil dengan sintetik-sintetiknya dari model bumi standard PREMAN dan IASPEI91 menunjukkan diskrepansi yang ramai, jika perbandingan dilaksanakan dalam domain waktu pada ketiga komponen gerak secara simultan, walaupun corner frequency yang dipasang adalah $20 \mathrm{mHz}$. Dijumpai diskrepansi yang nyata pada waveform berbagai fase gelombang body dan gelombang permukaan dalam perbandingan seismogram riil dengan sintetiknya, baik pada waktu tempuh, jumlah osilasi dan waktu tiba dari osilasi-osilasi akhir, khususnya pada gelombang S dan Love. Perbedaan ketebalan kulit bumi diantara kedua model bumi standard diperjelas oleh amplitudo seismogram sintetik, bahwa semakin tebal kulit bumi memberikan seismogram sintetik dengan amplitudo yang lebih tinggi dan jumlah osilasi yang lebih panjang pada gelombang $\mathrm{S}$ dan Love. Gelombang Love dengan panjang gelombang $150 \mathrm{~km}$ berreaksi signifikant terhadap perubahan pada ketebalan kulit bumi, gradien kecepatan $\beta_{h}$ dan nilai-nilai kecepatan S di upper mantle. Pencocokan seismogram pada gelombang permukaan Love dan Rayleigh juga memberikan kontribusi pada perbaikan perbandingan seismogram pada segmen waktu fase gelombang sekunder S, meskipun masih diperlukan koreksi kecepatan penjalaran gelombang hingga $\mathrm{CMB}$, hingga diperoleh pencocokan yang baik pada segmen waktu gelombang sekunder S, ScS, dan P. Model kecepatan seismik 1-D antara episenter gempa C081097A dengan stasiun-stasiun observasi yang didapatkan dari gambar-gambar di atas, berlaku sebagai model kecepatan rata-rata. Pada frekuensi yang lebih tinggi, misal $30 \mathrm{mHz}$, dijumpai diskrepansi yang tidak lagi sistimatis, jika seismogram dianalisis dengan waveform. Ini menunjukkan heterogenitas struktur bumi yang lebih kompleks,
[1] Woodhouse, J.H. \& Dziewonski, A.M., J. Geophys. Res., 89, 5953-5986 (1984)

[2] Tajima, F. \& Grand, S.P., J. Geophys. Res., 103, 15015-15036 (1998)

[3] IASPEI 1991, Seismological Tables, Research School of Earth Sciences, Australian National University, 1991

[4] Dziewonski, A.M. and Anderson, D.L., Phys. of the Earth and Plan. Int., 25, 297-356 (1981)

[5] Kennett, B.L.N., Gudmundsson, O. and Tong, C., Phys. of the Earth and Plan. Int., 86, 85-98 (1994)

[6] Okabe, A., Kaneshima, S., Kanjo, K. Ohtaki, T. and Purwana, I.,Phys. of the Earth and Plan. Int., 146, 101-112 (2003)

[7] Simons F. J. , Zielhuis A. and van der Hilst, R.D., Lithos, 48, 17-43 (1999)

[8] Debayle, E. and Kennett, B. L. N., Earth and Plan. Sci. Letters, 184, 339-351 (2000)

[9] Bagus J.S., Möglichkeiten und Grenzen der Modellierung vollständiger langperiodischer Seismogramme, Doktorarbeit, Berichte Nr. 12, Inst. für Geophysik, Uni. Stuttgart, 1999

[10] Gubbins, D., Seismology and Plate Tectonics (Cambridge University Press, Cambridge, 1990)

[11] Dalkolmo, J., Synthetische Seismogramme für eine sphaerisch symmetrische, nichtrotierende Erde durch direkte Berechnung der Greenschen Funktion, Diplomarbeit, Inst. fuer Geophys., Uni. Stuttgart, 1993

[12] Friederich, W. and Dalkolmo, J., Geophys. J. Int., 122, 537-550 (1995)

[13] Bulland, R. and Chapman, C., Bull. Seis. Soc. Am., 73, 12711302 (1983)

[14] Friederich W., 1997, Regionale, dreidimensionale Strukturmodelle des oberen Mantel aus der wellentheoritischen Inversion teleseismischer Oberflächenwellen, Berichte des Instituts für Geophysik der Universität Stuttgart, 9.

[15] Bagus J.S., Pengaruh ketebalan kulit bumi pada tinggi amplitudo gelombang P, Majalah IPTEK, Vol 15, No. 3, 1-6 (2004)

[16] Bagus J.S, Mempelajari Model Bumi Berlapis dengan Seismogram, Majalah IPTEK, Vol 13, No 3, 25-33 (2001)

[17] Dreger, D.S., Time-Domain Moment Tensor INVerse Code (TDMT_INVC), The Berkeley Seismological Laboratory (BSL), report number 8511, 2002

[18] Kennett, B.L.N. Engdahl, E.R. \& Buland R., Geophys J Int, 122, 108-124 (1995) 